This article is licensed under the Creative Commons Attribution-NonCommercial 4.0 International License (CC BY-NC) (http://www.karger.com/Services/OpenAccessLicense). Usage and distribution for commercial purposes requires written permission.

\title{
Anisakiasis of the Terminal Ileum Removed by Colonoscopy
}

\author{
Takeshi Okamoto Katsuyuki Fukuda \\ Department of Gastroenterology, St. Luke's International Hospital, Tokyo, Japan
}

\section{Keywords}

Anisakiasis $\cdot$ Parasite $\cdot$ Small intestine $\cdot$ Colonoscopy

\begin{abstract}
A 35-year-old Japanese man with no significant medical history presented to the emergency department complaining of abdominal pain, nausea, and vomiting $35 \mathrm{~h}$ after ingesting raw horse mackerel, sardines, and tuna. Computed tomography of the abdomen with intravenous contrast revealed significant thickening of the terminal ileum with mild proximal dilatation and moderate ascites. On colonoscopy, an actively moving anisakis larva was discovered in the terminal ileum. The larva was removed with endoscopic forceps. The patient's symptoms resolved quickly following the procedure.

(C) 2021 The Author(s)

Published by S. Karger AG, Basel
\end{abstract}

\section{Introduction}

Anisakiasis is caused by consuming larvae of anisakis, a parasitic nematode found in seafood. First reported by van Thiel et al. [1] in 1960, the parasitic infection is common in areas such as Japan where raw fish are consumed regularly. Almost all cases are associated with

Takeshi Okamoto
Department of Gastroenterology, St. Luke's International Hospital
$9-1$ Akashicho, Chuo-ku
Tokyo 104-8560 (Japan)
okamotot@luke.ac.jp




\section{Case Reports in Gastroenterology}

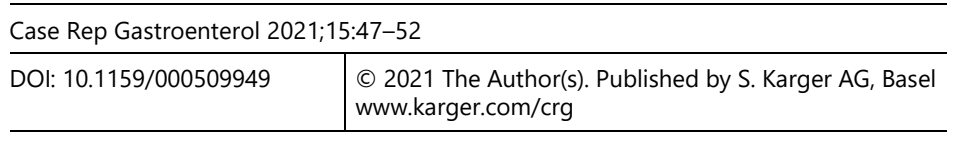

Okamoto and Fukuda: Anisakiasis of the Terminal Ileum Removed by Colonoscopy

ingestion of raw or undercooked seafood such as cod, tuna, squid, salmon, shark, mackerel, and possibly raw clams [2,3]. Anisakis most commonly affects the stomach but may affect any part of the gastrointestinal tract, as well as extraintestinal sites such as the liver and pancreas $[4,5]$.

Small bowel anisakiasis (SBA) is rare compared to gastric anisakiasis. While gastric anisakiasis generally presents with sharp abdominal pain, SBA may also present with small bowel obstruction due to localized bowel edema resulting from an allergic response to the parasite. The small bowel presents hurdles for both diagnosis and treatment as endoscopic access is limited. While a recent history of raw fish ingestion, serum antibody titers and/or characteristic computed tomography (CT) findings can lead to a presumptive diagnosis, treatment is usually conservative. Here, we present the first report in English of anisakiasis of the terminal ileum confirmed and removed by colonoscopy.

\section{Case Report/Case Presentation}

A 35-year-old Japanese man with no significant medical history presented to the emergency department complaining of abdominal pain, nausea, and vomiting $35 \mathrm{~h}$ after ingesting raw horse mackerel, sardines, and tuna. Vital signs were normal. Physical examination revealed tenderness to palpation in the epigastrium with no rebound tenderness and a tympanic sound upon percussion. Laboratory tests were significant for leukocytosis $\left(13,500 / \mathrm{mm}^{3}\right)$ with no eosinophilia and elevated C-reactive protein $(2.07 \mathrm{mg} / \mathrm{dL})$. Contrast CT of the abdomen revealed significant edema of the terminal ileum with mild proximal dilatation and moderate ascites (Fig. 1). Inflammation appeared to reach the ileocecal valve, suggesting that the affected site may be accessible colonoscopically.

Colonoscopy was performed using PCF-Q260AZI (Olympus Corp., Tokyo, Japan) after bowel preparation, as the patient was able to pass gas. An actively moving anisakid larva was discovered in the terminal ileum, which was removed with endoscopic forceps (Fig. 2). The patient's symptoms quickly resolved following the procedure. He was discharged free of symptoms two days later. Serum titer of anti-anisakis IgG/A antibody was later found to be positive $(1.73$, normal range $<1.50)$.

\section{Discussion/Conclusion}

While SBA was initially estimated to account for less than $5 \%$ of anisakiasis in humans, recent estimates of its incidence have been as high as $30.5 \%$ of anisakiasis cases [6-8]. SBA patients tend to be older, male, regular drinkers, and have higher heart rates and CRP than gastric anisakiasis patients [8]. Anisakid larvae in the small bowel have a predilection for the ileum, particularly the terminal ileum $[9,10]$. Symptoms generally occur within 5 days of ingestion and most commonly include abdominal pain, nausea, and vomiting with or without bowel obstruction. Hemorrhagic shock, intussusception, and perforation have also been reported $[7,11,12]$.

\section{Karger'=}




\section{Case Reports in Gastroenterology}

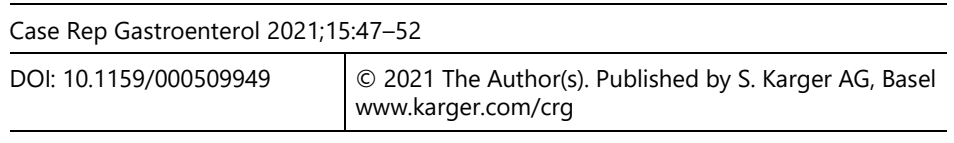

Okamoto and Fukuda: Anisakiasis of the Terminal Ileum Removed by Colonoscopy

The low historical incidence may be the result of underdiagnosis as well as underreporting. Whereas gastric anisakiasis can be confirmed by directly visualizing larvae during esophagogastroduodenoscopy, there is no gold standard for the diagnosis of SBA. SBA is diagnosed clinically, radiologically, and/or with anti-anisakis IgG/A titers. Titers have a moderate sensitivity of $70 \%$ and specificity of $87 \%[13,14]$. Common CT findings such as segmental intestinal edema presenting with the "target sign" accompanied by proximal dilatation, fat stranding, and ascites are seen in most patients but must be differentiated from other sources of inflammation as well as tumors $[9,10,15]$. While 2 cases of larva detection with capsule endoscopy have been reported, bowel obstruction must be ruled out before conducting this examination $[16,17]$.

Standard therapy for SBA has not been established. Conservative treatment is generally effective, although patients are admitted for an average of 9 days and about $7 \%$ require surgery $[7,11]$. Cases of successful treatment using Gastrografin or steroids with antihistamines have been reported $[18,19]$. However, endoscopic removal is the only available method of removing the causative parasite without surgery.

Searches on PubMed and Ichushi revealed no reports of endoscopic removal for SBA in English and 6 reports in Japanese (Table 1) [20-25]. The ileum was affected in all cases. Two cases were treated with a double-balloon enteroscope, while the other 5 cases including our case were treated with a colonoscope. All 7 cases experienced immediate relief after the procedure. While double-balloon enteroscopy is not widely available, the terminal ileum can be approached with a regular colonoscope. Long colonoscopes such as PCF-H290ZL (Olympus) are longer than regular colonoscopes and may be useful if a more proximal portion of the ileum is involved. Bowel perforation and obstruction must be ruled out before considering bowel preparation.

In conclusion, we report a case of anisakiasis of the terminal ileum which was confirmed and treated using a colonoscope. Endoscopic treatment has led to immediate symptomatic relief in all successful cases in the literature and may be a viable option in selected patients.

\section{Statement of Ethics}

The patient has given his written informed consent to publish this case (including publication of images). The identity of the patient has been protected.

\section{Conflict of Interest Statement}

The authors have no conflicts of interest to declare.

\section{Funding Sources}

None.

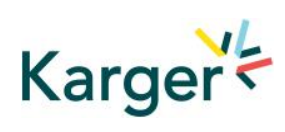




\section{Case Reports in Gastroenterology}

Case Rep Gastroenterol 2021;15:47-52

DOI: $10.1159 / 000509949$

(c) 2021 The Author(s). Published by S. Karger AG, Basel www.karger.com/crg

Okamoto and Fukuda: Anisakiasis of the Terminal Ileum Removed by Colonoscopy

\section{Author Contributions}

Takeshi Okamoto wrote the manuscript, diagnosed the patient, and performed the colonoscopy. Katsuyuki Fukuda edited the manuscript. Both gave final approval of the manuscript.

\section{References}

1 van THIEL P, Kuipers FC, Roskam RT. A nematode parasitic to herring, causing acute abdominal syndromes in man. Trop Geogr Med. 1960 Jun;12:97-113.

2 Furuya K, Nakajima H, Sasaki Y, Urita Y. Anisakiasis: the risks of seafood consumption. Niger J Clin Pract. 2018 Nov;21(11):1492-4.

3 Shweiki E, Rittenhouse DW, Ochoa JE, Punja VP, Zubair MH, Baliff JP. Acute Small-Bowel Obstruction From Intestinal Anisakiasis After the Ingestion of Raw Clams; Documenting a New Method of Marine-to-Human Parasitic Transmission. Open Forum Infect Dis. 2014 Sep;1(2):ofu087.

4 Yamato H, Kawakami H, Takagi K, Ogawa K, Hatanaka K, Yamamoto Y, et al. Acute pancreatitis caused by Anisakis. Gastrointest Endosc. 2014 Apr;79(4):676-8.

5 Kita R, Hashida H, Uryuhara K, Kaihara S. Hepatic anisakiasis mimicking metastatic liver tumour. Int J Surg Case Rep. 2019;60:209-12.

6 Ishikura H, Kikuchi K, editors. Intestinal Anisakiasis in Japan: Infected Fish, Sero-Immunological Diagnosis, and Prevention [in Japanese]. Tokyo: Springer; 1990. https://doi.org/10.1007/978-4-431-68299-8.

7 Yasunaga H, Horiguchi H, Kuwabara K, Hashimoto H, Matsuda S. Clinical features of bowel anisakiasis in Japan. Am J Trop Med Hyg. 2010 Jul;83(1):104-5.

8 Yamamoto K, Takahashi O, Kobayashi D. Comparison of risk factors between human intestinal and gastric Anisakiasis. Parasitol Int. 2020 Apr;75:102024.

9 Lee JS, Kim BS, Kim SH, Park JK, Choi G, Hwang IK, et al. Acute invasive small-bowel Anisakiasis: clinical and CT findings in 19 patients. Abdom Imaging. 2014 Jun;39(3):452-8.

10 Ripollés T, López-Calderón LE, Martínez-Pérez MJ, Salvador J, Vizuete J, Vila R. Usefulness of Ultrasound in the Diagnosis of Intestinal Anisakiasis. J Ultrasound Med. 2020 Mar;9999:1-6.

11 Shimamura Y, Muwanwella N, Chandran S, Kandel G, Marcon N. Common Symptoms from an Uncommon Infection: gastrointestinal Anisakiasis. Can J Gastroenterol Hepatol. 2016;2016:5176502.

12 Kawashima K, Fujiwara T, Katakura K, Gunji N, Yokokawa A, Sakamoto A, et al. Anisakiasis in the Small Intestine with Excessive Bleeding That Was Difficult to Diagnose Endoscopically. Intern Med. 2019 Jan;58(1):63-6.

13 Okazaki M, Goto I, Kurokawa I. Studies on the detection of anti-Anisakis larvae antibodies by ELISA kits [in Japanese]. Med Pharmacol. 1992;27:971-7.

14 Matsushita M, Okazaki K. Serologic test for the diagnosis of subclinical gastric anisakiasis. Gastrointest Endosc. 2005 Jun;61(7):931.

15 Shibata E, Ueda T, Akaike G, Saida Y. CT findings of gastric and intestinal anisakiasis. Abdom Imaging. 2014 Apr;39(2):257-61.

16 Nakaji K. Enteric anisakiasis which improved with conservative treatment. Intern Med. 2009;48(7):573.

17 Hashimoto R, Matsuda T, Nakahori M. Small bowel anisakiasis detected by capsule endoscopy [in Japanese]. Dig Endosc. 2017 Jan;29(1):126-7.

18 Fujikawa H, Kuwai T, Yamaguchi T, Miura R, Sumida Y, Takasago T, et al. Gastric and enteric anisakiasis successfully treated with Gastrografin therapy: A case report. World J Gastrointest Endosc. 2018 Mar;10(3):69-73.

19 Toyoda H, Tanaka K. Intestinal Anisakiasis Treated Successfully with Prednisolone and Olopatadine Hydrochloride. Case Rep Gastroenterol. 2016 May;10(1):30-5.

20 Yasumizu T, Hirano M, Nakano H, Tomonari K, Ii K, Tsunetomi N, et al. Endoscopic treatment of terminal ileal anisakiasis: a case report [in Japanese]. Gastroenterol Endosc. 1998;40:818-23.

21 Sato T, Imaeda H, Ogata H, Iwao Y, Hosoda Y, Naganuma M, et al. A case of ileal anisakiasis removed by colonoscopy [in Japanese]. Prog Dig Endosc. 2001;58(2):112-3. 


\section{Case Reports in Gastroenterology}

\begin{tabular}{l|l}
\hline Case Rep Gastroenterol 2021;15:47-52 \\
\hline DOI: 10.1159/000509949 & $\begin{array}{l}\text { @ 2021 The Author(s). Published by S. Karger AG, Basel } \\
\text { www.karger.com/crg }\end{array}$ \\
\hline
\end{tabular}

Okamoto and Fukuda: Anisakiasis of the Terminal lleum Removed by Colonoscopy

22 Amano M, Fukumoto A, Yamao K, Imagawa H, Hashimoto Y, Iiboshi T, et al. Successful treatment of enteric anisakis through endoscopic extraction using a double-balloon enteroscope [in Japanese]. Gastroenterol Endosc. 2013;55:1643-9.

23 Takahara H, Takahara S. A case of ileal anisakiasis in which the anisakis larva was removed with doubleballoon endoscopy [in Japanese]. Gastroenterol Endosc. 2013;55:22-7.

24 Kawada A, Sasaki S, Iwasaki T, Kojima K, Nakayama M, Uchida K, et al. A case of ileal anisakiasis in which the anisakis larva was removed by endoscopy [in Japanese]. Kochi Red Cross Hospital Igaku Zasshi. 2015;20:158.

25 Murakami T, Takahashi A, Kimura R, Baba T, Satoi A, Makino T, et al. A case of ileal anisakiasis in which the anisakis larva was removed by colonoscopy [in Japanese]. Prog Dig Endosc. 2018;92(1):128-9.

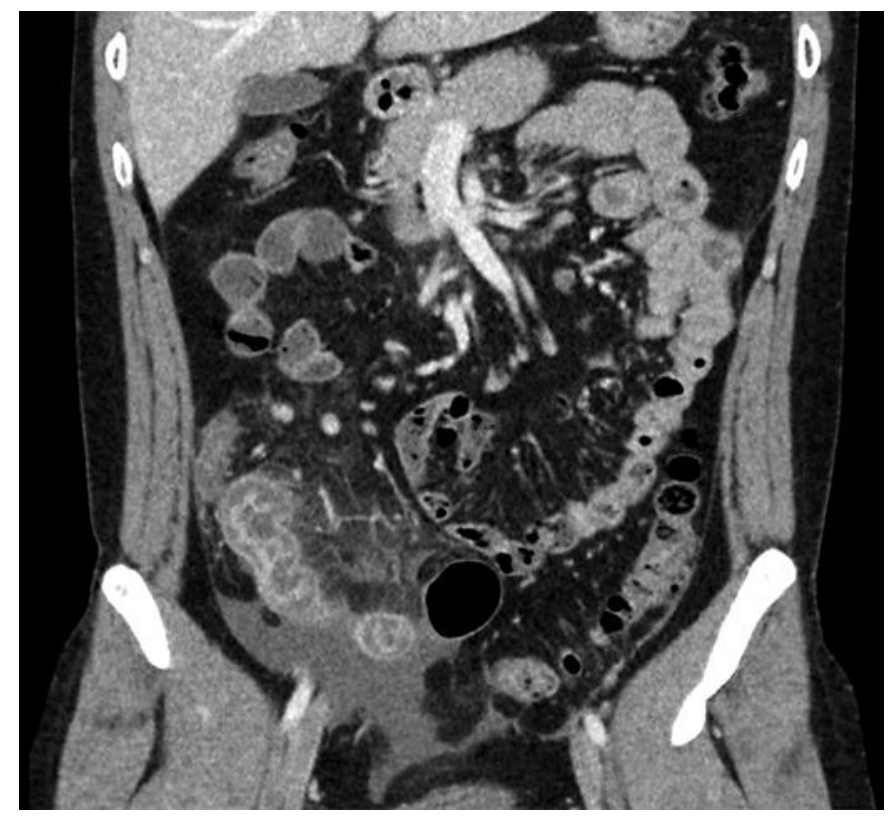

Fig. 1. Contrast CT of the abdomen revealed significant edema of the terminal ileum with mild proximal dilatation and moderate ascites. 


\section{Case Reports in Gastroenterology}

Case Rep Gastroenterol 2021;15:47-52 (c) 2021 The Author(s). Published by S. Karger AG, Basel www.karger.com/crg

Okamoto and Fukuda: Anisakiasis of the Terminal Ileum Removed by Colonoscopy
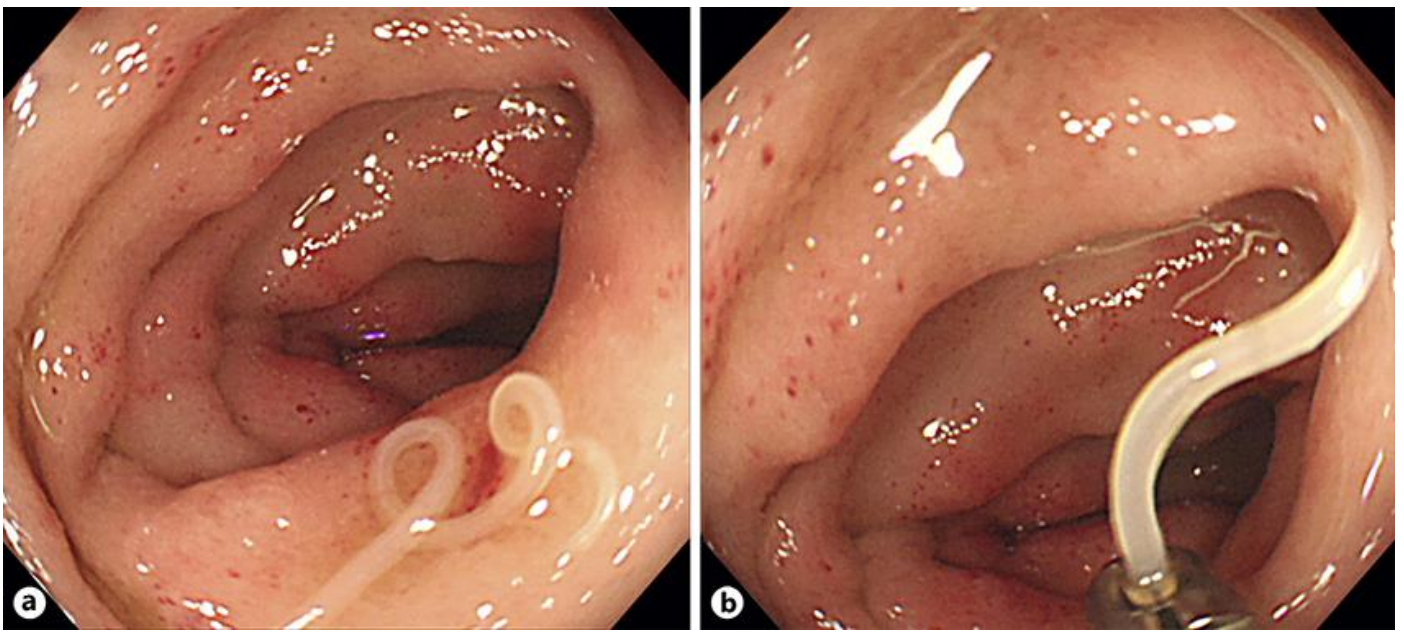

Fig. 2. Anisakid larva discovered on colonoscopy (a) was successfully removed with endoscopic forceps (b).

Table 1. Reports of small bowel anisakiasis treated endoscopically

\begin{tabular}{|c|c|c|c|c|c|c|c|c|c|c|c|c|c|c|}
\hline Case & Author & Year & Age & Gender & Symptoms & $\begin{array}{l}\text { Time from raw } \\
\text { fish ingestion } \\
\text { to onset }\end{array}$ & $\begin{array}{l}\text { Anisakis } \\
\text { IgG/A anti- } \\
\text { body }\end{array}$ & Temperature, & $\begin{array}{c}{ }^{\circ} \mathrm{C} \text { WBC, } \\
/ \mu \mathrm{L}\end{array}$ & $\begin{array}{l}\text { EOS, } \\
\%\end{array}$ & $\begin{array}{l}\text { CRP, } \\
\mathrm{mg} / \mathrm{dL}\end{array}$ & Endoscope & Location & Result \\
\hline 2 & Sato & 2001 & 30 & Female & $\mathrm{AP}, \mathrm{D}$ & NA & NA & 36.9 & 3,900 & 5.2 & 0.07 & Colonoscope & $\begin{array}{l}\text { Terminal il- } \\
\text { eum }\end{array}$ & $\begin{array}{l}\text { Immediate } \\
\text { relief }\end{array}$ \\
\hline 3 & Takahara & 2013 & 31 & Female & $\mathrm{AP}, \mathrm{N}$ & $15 \mathrm{~h}$ & - & 36.9 & 10,300 & 0 & 2.08 & DBE & Ileum & $\begin{array}{l}\text { Immediate } \\
\text { relief }\end{array}$ \\
\hline 4 & Amano & 2013 & 52 & Male & $\mathrm{AP}$, urticaria & 2 days & + & 36.2 & 7,640 & 2.5 & 7.55 & DBE & Ileum & $\begin{array}{l}\text { Immediate } \\
\text { relief }\end{array}$ \\
\hline 5 & Kawata & 2015 & 29 & Male & $\mathrm{AP}$ & $2 \mathrm{~h}$ & - & 36.5 & 7,660 & 1.8 & 1.66 & Colonoscope & $\begin{array}{l}\text { Terminal il- } \\
\text { eum }\end{array}$ & $\begin{array}{l}\text { Immediate } \\
\text { relief }\end{array}$ \\
\hline 6 & Murakami & 2018 & 61 & Male & $\mathrm{AP}$ & 1 day & + & 35.1 & 11,100 & 1.6 & 0.57 & Colonoscope & $\begin{array}{l}\text { Terminal il- } \\
\text { eum }\end{array}$ & $\begin{array}{l}\text { Immediate } \\
\text { relief }\end{array}$ \\
\hline 7 & Our case & 2020 & 35 & Male & $A P, N, V$ & $35 \mathrm{~h}$ & + & 37.3 & 13,500 & 2.8 & 2.07 & Colonoscope & $\begin{array}{l}\text { Terminal il- } \\
\text { eum }\end{array}$ & $\begin{array}{l}\text { Immediate } \\
\text { relief }\end{array}$ \\
\hline
\end{tabular}

AP, abdominal pain; CRP, C-reactive protein; DBE, double-balloon enteroscope; EOS, eosinophils; N, nausea; NA, not available; V, vomiting; WBC, white blood cells. 